\title{
Contributions of Electron Microscopic Spreading Preparations ("Miller Spreads") to the Analysis of Chromosome Structure
}

\author{
U. SCHEER $^{1}$
}

\section{Introduction}

Before introduction of the chromatin spreading technique by Miller and Beatty in 1969 (Miller and Beatty $1969 \mathrm{a}-\mathrm{d}$ ), relatively limited information was available concerning the submicroscopic organization of chromosomes in mitosis and interphase. Thus, at the end of the 1960s the general picture that emerged from inspection of ultrathin sections of cell nuclei, isolated chromatin, and of whole mount preparations was that mitotic chromosomes and interphase chromatin consisted of a complex meshwork of irregularly sized and knobby fibers with diameters ranging from 20 to $30 \mathrm{~nm}$ (for reviews see Ris 1969; DuPraw 1970; Solari 1974; Ris and Korenberg 1979; Hozier 1979). Although the internal organization of chromatin fibers was particularly suitable for study by surface spreading on an air-water interface, originally introduced by Gall (1963), neither a discrete subunit organization was recognized nor could the "thick" chromatin fibers be reproducibly unfolded into thinner fibers which were believed to be transcriptionally active (Gall 1966). Hence, electron microscopic methods were unavailable to study features of chromosomes during interphase, i.e., their functional subdivision into transcriptionally active and inactive domains.

A technical breakthrough came with the chromatin spreading technique developed by O. Miller and co-workers (Miller and Beatty $1969 \mathrm{a}-\mathrm{d}$; Miller and Hamkalo 1972; Miller and Bakken 1972; Hamkalo and Miller 1973; Hamkalo et al. 1973). This spreading procedure was designed to unfold chromatin gently, but extensively by exposure to a medium of very low ionic strength at slightly alkaline $\mathrm{pH}$ and to avoid mechanical stress due to surface tensions. The "Miller spreading", as the preparation is often referred to, unraveled chromosomes and interphase chromatin to the first level of the nucleoprotein organization and permitted visualization of transcript fibrils which remained associated with the extended chromatin filaments. In fact, the first papers published by Miller and Beatty (1969a-d) described the morphological features of transcriptionally active genes while only later, in 1973, Olins and Olins and independently Woodcock drew attention to repeating globular subunit structures present in transcriptionally inactive chromatin fibers prepared from a variety of cells according to the Miller procedure (Olins and Olins 1973; Woodcock 1973).

${ }^{1}$ Institute of Zoology I, University of Würzburg, Röntgenring 10, 8700 Würzburg, FRG. 
It is obvious that one essential step of the Miller spreading technique is the extensive unfolding of chromatin by hypotonic media in order to disrupt all higher levels of chromosomal arrangements as they exist in the living cell. Although modifications of the Miller procedure (e.g., inclusion of salt in the dispersal medium, very brief exposure to low salt medium) have also been successfully applied to the study of higher order, supranucleosomal packaging of chromatin and to identify intermediate, transitory states during experimentally induced relaxation (see, e.g., Hozier 1979; Zentgraf et al. 1980 a, b, 1981; Hamkalo et al. 1981; Labhart et al. 1982), such aspects will not be considered in the present chapter. Rather, this overview focuses on molecular aspects of chromatin organization with special emphasis on structural modifications that are concerned with transcription. Furthermore, more recent developments of the Miller chromatin spreading method will be discussed which combine immunolocalization and in situ hybridization techniques. Such applications of the chromatin spreading method are of great potential value for identification of DNA- and RNA-associated proteins and the genetic content of specific transcription units.

\section{The Nucleosome Chain: The Elementary Structural Component of Chromosomes}

When mitotic chromosomes or interphase chromatin preparations are unfolded by exposure to a buffer of very low ionic strength (e.g., $0.1 \mathrm{mM} \mathrm{Na}$-borate buffer, $\mathrm{pH}$ 8-9) and centrifuged onto an electron microscopic grid essentially as described in detail by Miller and Hamkalo (1972), Miller and Bakken (1972), and Hamkalo and Miller (1973), the bulk of the transcriptionally inactive chromatin displays the characteristic linear arrays of closely packed particles, the nucleosomes, connected by thin filaments representing linker DNA (Fig. 1 a, b). Such extended beaded chains were first described by Olins and Olins $(1973,1974)$ and Woodcock (1973; Woodcock et al. 1976); the term nucleosome was introduced by Oudet et al. (1975). The beaded chromatin fiber or primary nucleofilament organization has been found in all eukaryotic species so far studied with the notable exception of some dinoflagellates which do not contain histones (Herzog and Soyer 1981). Thus, chromatin of plant and animal species is morphologically indistinguishable in Miller spreads (e.g., chromatin from human HeLa cells and amphibian oocytes; Fig. 1 a, b; amphibian and avian erythrocytes, Drosophila polytene chromosomes, Chlamydomonas: Woodcock et al. 1976; rat and chicken: Olins et al. 1975; Zentgraf et al. 1980 a; sea urchin sperm: Zentgraf et al. 1980 b; Physarum polycephalum: Scheer et al. 1981; Dytiscus marginalis: Scheer and Zentgraf 1978; Drosophila melanogaster: McKnight and Miller 1976; Oncopeltus fasciatus: Foe 1978; Cyclops furciper: Beermann 1984; Zea mays: Zentgraf et al. 1981; Greimers and Deltour 1981; Allium cepa and Sambucus nigra: Lutz and Nagl 1980; cultured mammalian cells of various origin: Howze et al. 1976; Franke et al. 1978; Hamkalo et al. 1981; Labhart et al. 1982).

The packing of DNA into a repeating subunit structure has also been established by biochemical and physicochemical methods and it is fascinating to follow 


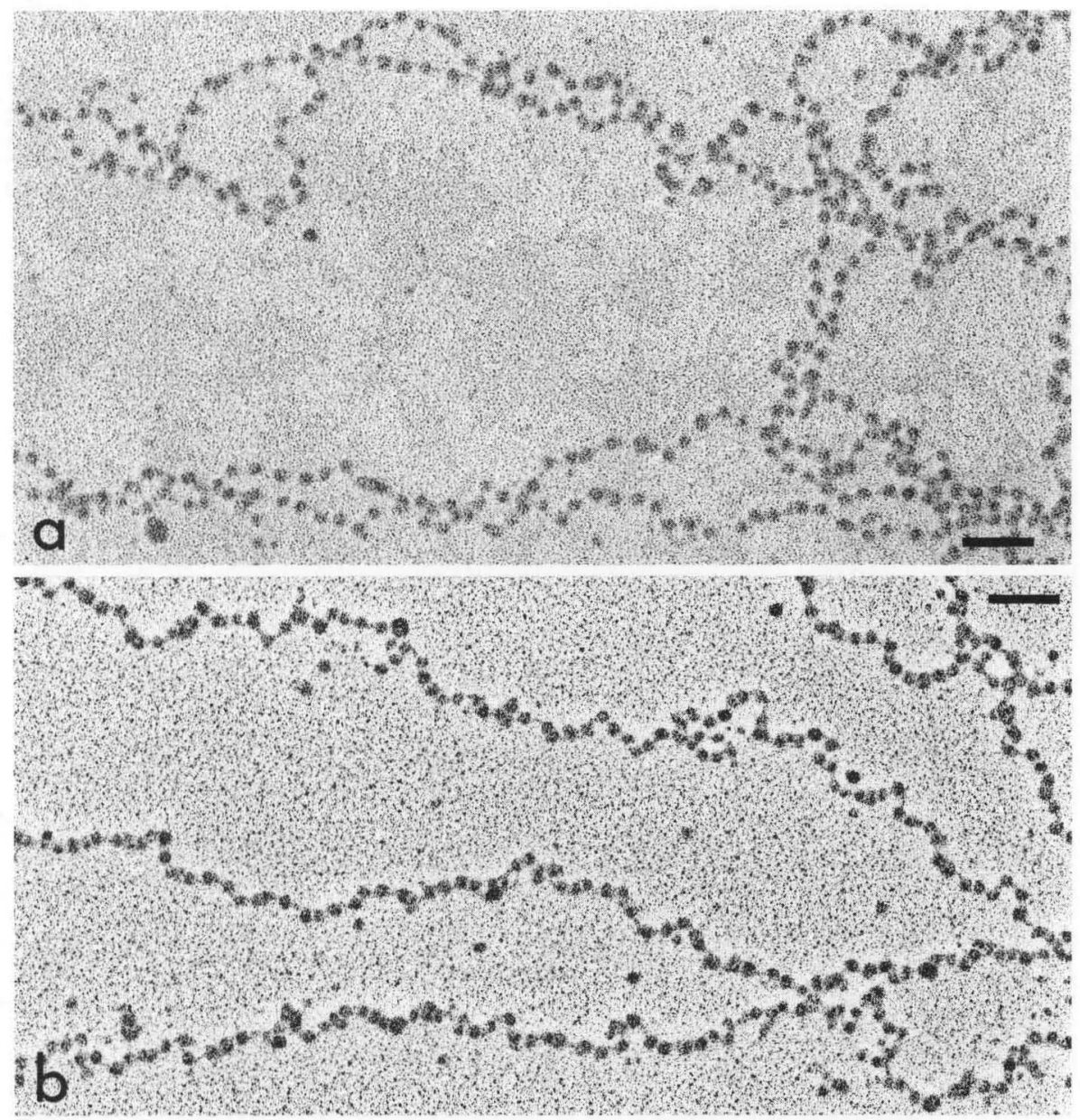

Fig. 1 a, b. Electron microscopic appearance of transcriptionally inactive chromatin in Miller spreads. Chromatin from human HeLa cells (a) and oocytes of the salamander Pleurodeles waltlii (b) was unfolded by exposure to very low salt conditions prior to centrifugation onto electron microscopic grids. The chromatin fibers are composed of linear arrays of globular subunits, the nucleosomes. $\times 80000$; bars $=0.1 \mu \mathrm{m}$

how the data, obtained by various methods, were eventually integrated into the nucleosome model (for reviews see McGhee and Felsenfeld 1980; Igo-Kemenes et al. 1982; Kornberg 1977). Since each nucleosome contains about 200 base pairs (bp) of DNA (with an extended length of the B-form of $200 \times 3.4 \AA=680 \AA$ ), the coiling of the DNA around the nucleosome core with a diameter of approximately $110 \AA$ results in an apparent foreshortening of the DNA by a factor of about 6 . In Miller spreads nucleosomes are usually somewhat distantly spaced (Fig. $1 \mathrm{a}, \mathrm{b}$ ) so that the apparent contraction ratio of DNA is only about two to three. 


\section{Visualization of Transcribing rRNA Genes}

The amplified ribosomal RNA (rRNA) genes of amphibian oocytes were the first genes visualized by electron microscopy (Miller and Beatty 1969 a-d; Figs. 2 and 3). Subsequently numerous investigators employed the Miller technique to

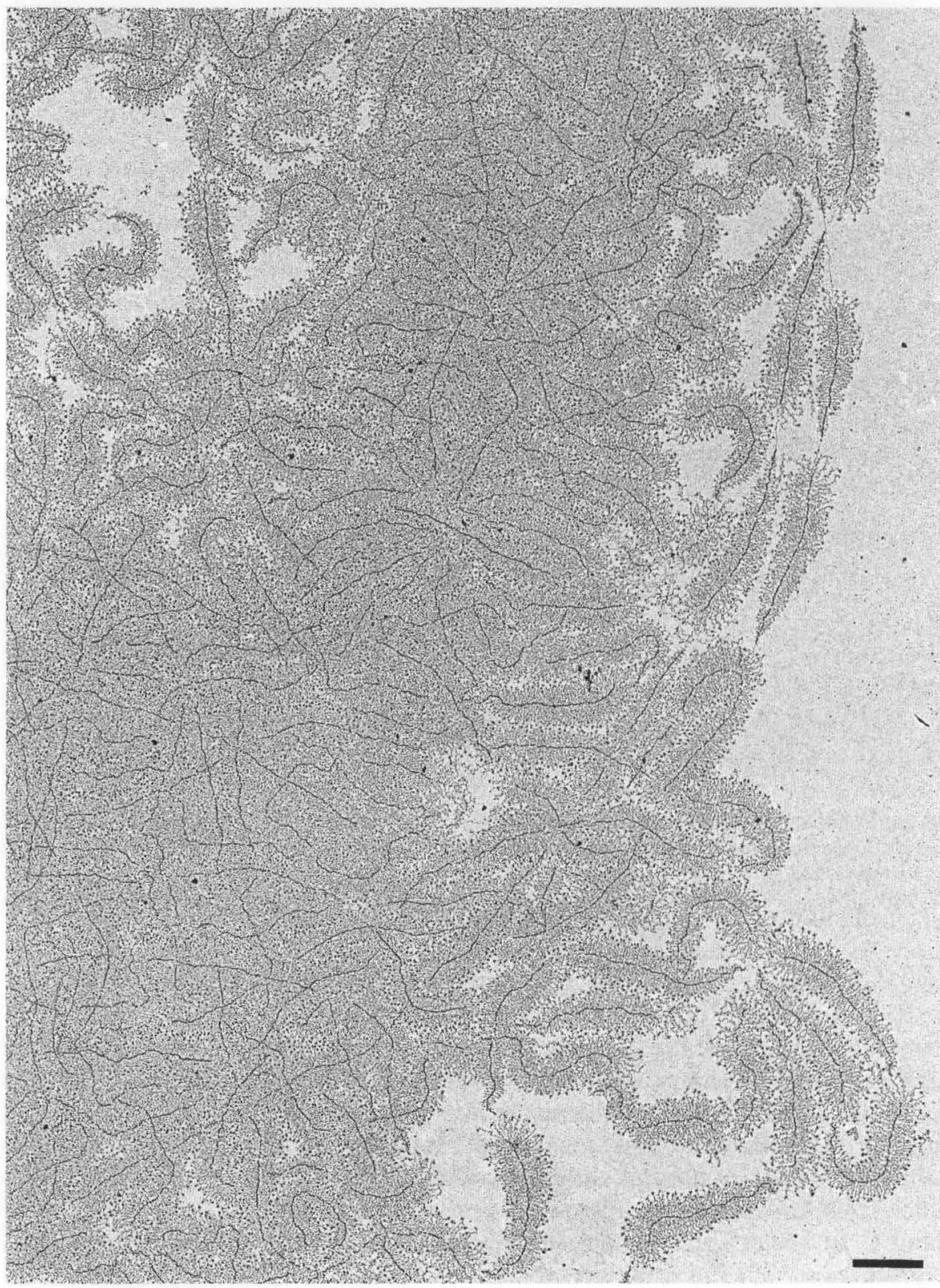

Fig. 2. Survey electron micrograph of spread nucleolar chromatin from a mid-sized Pleurodeles oocyte. This oogenic stage is characterized by intense synthesis of rRNA. $\times 9000 ; b a r=1 \mu \mathrm{m}$ 


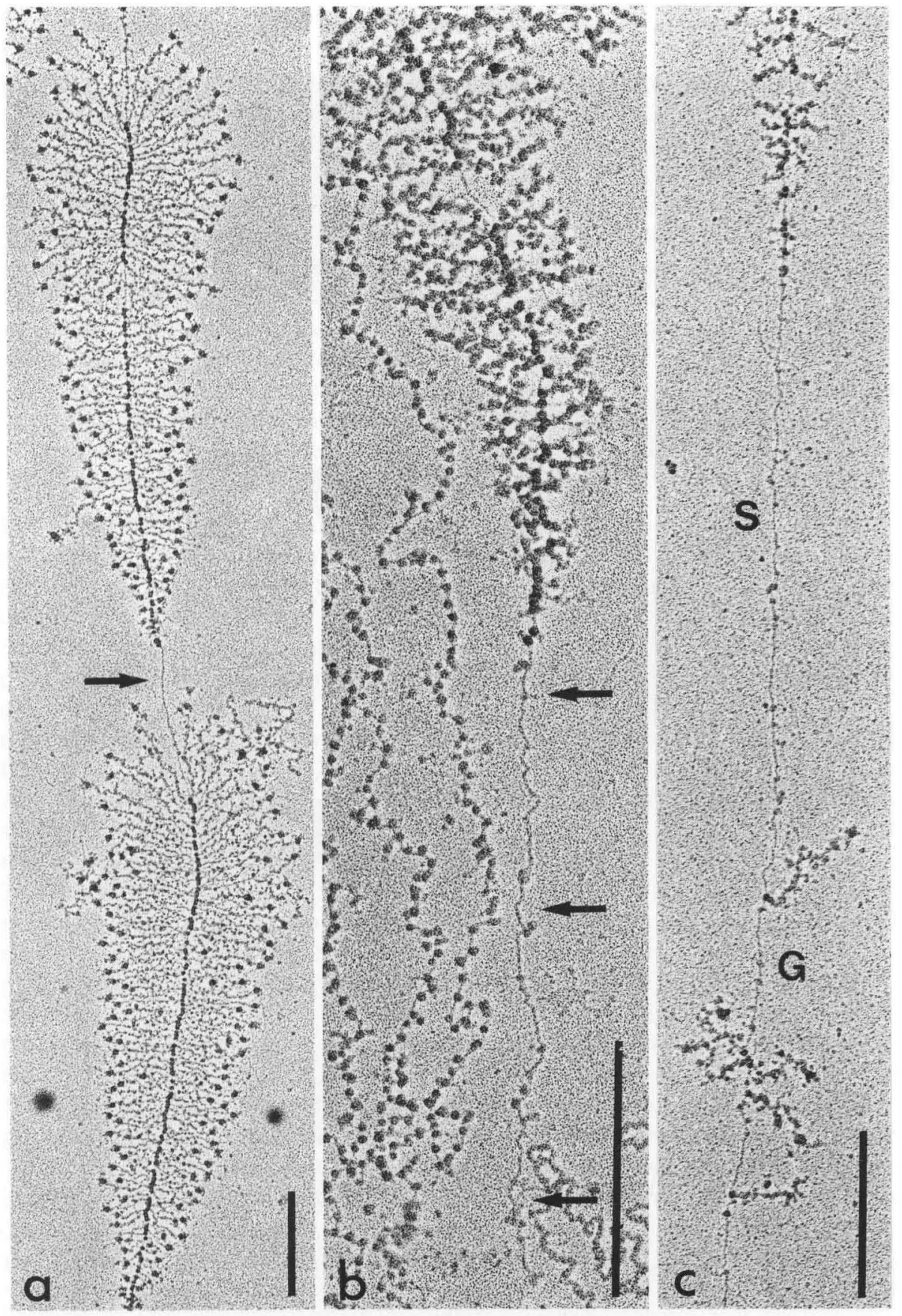

Fig. 3 a-c. Structural details of transcribed rRNA genes as seen in Miller spreads. a Two tandemly arranged rRNA genes from a Pleurodeles oocyte. Note the high packing density of the RNA polymerases and the smooth configuration of the spacer region (arrow). b Higher magnification of the spacer region (arrows) and the proximal portion of an rRNA gene from an oocyte of Triturus cristatus. The spacer chromatin is clearly different from adjacent inactive chromatin fibers which reveal the characteristic nucleosome arrangement. $\mathbf{c}$ The smooth, nonnucleosomal chromatin conformation is maintained in the spacer $(S)$ and the gene $(G)$ regions in stages of reduced transcriptional activity (spread preparation from a mature oocyte of Triturus cristatus). $\mathbf{a} \times 28000 ; \mathbf{b} \times 70000 ; \mathbf{c} \times 45000 ;$ bars $=0.5 \mu \mathrm{m}$ 


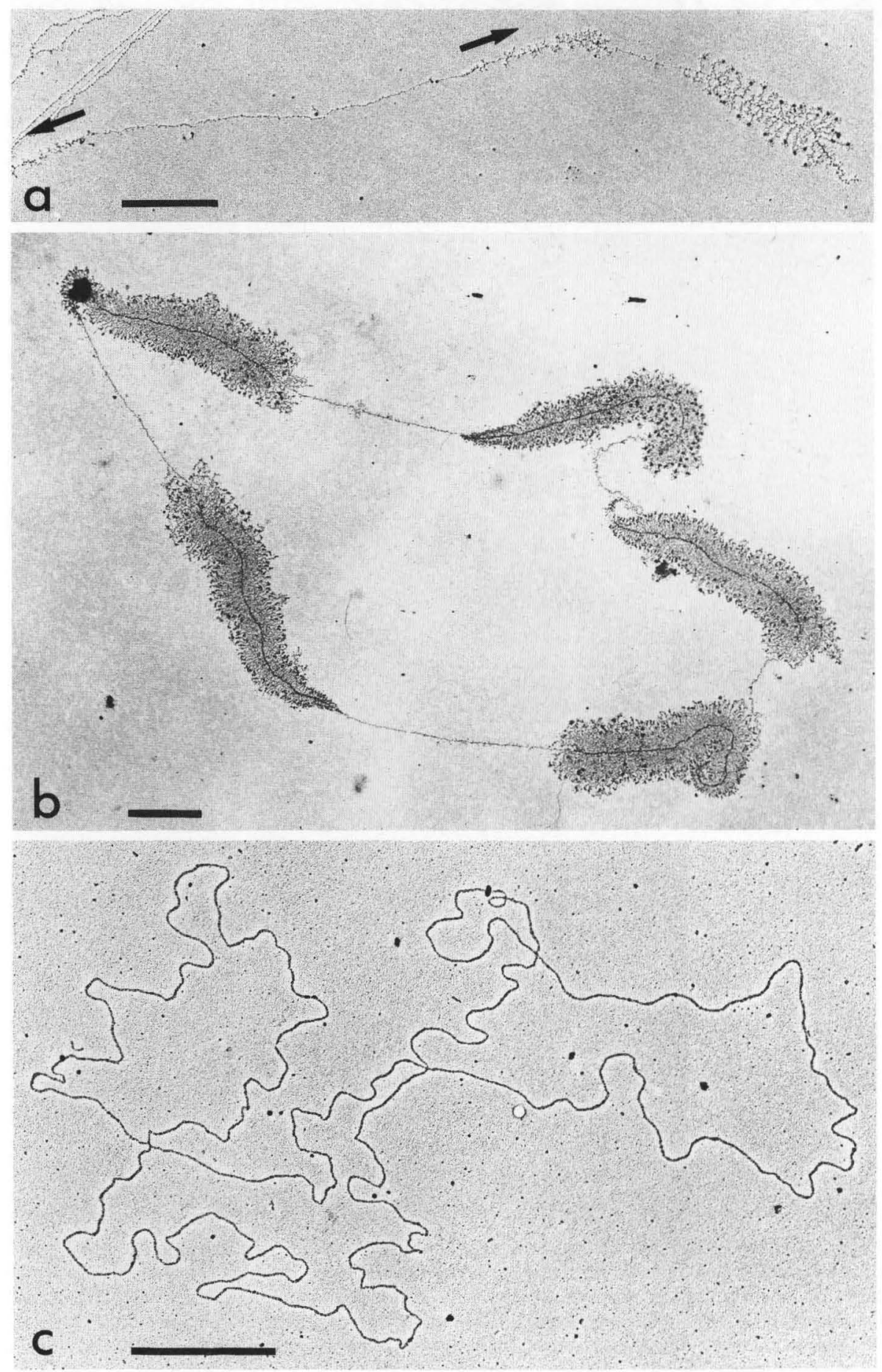

Fig. $4 a-c$ 
analyze transcribing rRNA genes from a variety of plant and animal cells (for reviews see Miller and Hamkalo 1972; Miller and Bakken 1972; Hamkalo and Miller 1973; Hamkalo et al. 1973; Chooi 1976; Franke and Scheer 1978; Franke et al. 1979; McKnight et al. 1979; Miller 1981, 1984; Scheer and Zentgraf 1982; Berger and Schweiger 1982; Puvion-Dutilleul 1983; Trendelenburg 1983). Figures 2 to 4 illustrate the appearance of rRNA genes from amphibian and insect oocytes and from the slime mold, Physarum polycephalum. Since the rDNA of Xenopus laevis has been completely sequenced, the ribosomal transcription units of this species can be correlated precisely with specific DNA sequences (e.g., SollnerWebb et al. 1982; Bakken et al. 1982).

In spite of extensive interspecies differences in the lengths of transcription units, the interspersed nontranscribed spacers and the resulting repeat units (for a compilation of quantitative data see Franke et al. 1979), several common characteristic features of rRNA genes emerged from these studies.

1. The chromatin axis of active rRNA genes is usually densely covered by RNA polymerase I-containing particles from which the transcript fibrils extend laterally. The lateral fibrils, containing nascent pre-rRNA chains, gradually increase in length in the direction of transcription so that the characteristic "Christmas trees" are formed (Figs. 2 and 3 a). The free ends of the transcripts are often accentuated by a terminal knob. In most transcription units the lateral fibrils increase in length as a function of the distance from the transcription initiation site, although the length increment seems to be lower or almost zero for the more distal transcripts (Franke et al. 1976 a; Laird et al. 1976; Puvion-Dutilleul et al. 1977; Angelier et al. 1979). In Dictyostelium, the fibril length gradient is interrupted, suggesting that processing of the nascent pre-rRNA takes place at a specific period during transcription (Grainger and Maizels 1980).

2. In most species, multiple rRNA genes are arranged in tandem with identical polarities along a given chromatin strand and are separated from each other by nontranscribed spacers (Fig. 3 a). It should be noted, however, that at least in amphibians, the so-called nontranscribed spacer might, in fact, be transcribed. Spacer transcripts arranged in defined transcription units are not infrequently found in Miller spreads of Xenopus laevis oocytes and seem to originate from the reduplicated promotor-like sequences in the spacer DNA (cf. Trendelenburg 1981; Morgan et al. 1983). There are, however, notable exceptions to the familiar gene-spacer-gene pattern. The rRNA genes of certain unicellular green algae are tightly clustered without detectable spacers or are arranged with alternating polarities along the chromatin axis (Berger and Schweiger 1982). Opposite polarities

Fig. 4. a Linear nucleolar chromatin strand from the slime mold Physarum polycephalum with two rRNA genes at either end in opposite polarities (the direction of transcription is indicated by the arrows; only the proximal part of the left transcription unit is shown). The intergenic nontranscribed region is compacted into nucleosomes. In such Miller spreads the intergene region has an average length of $4.4 \mu \mathrm{m}$ as compared to the extended length of the corresponding DNA (B-form) of $8.5 \mu \mathrm{m}$ (cf. Seebeck and Braun 1982). b Nucleolar chromatin ring with five repeating units from an oocyte of the water beetle, Dytiscus marginalis. The contour length of the ring shown is $35 \mu \mathrm{m}$. c rDNA circle isolated from Dytiscus nucleolar chromatin with a contour length of $34.3 \mu \mathrm{m}$ (cytochrome c-surface spreading). Molecules of this size class represent 5-gene rings. 
of adjacent rRNA genes are also present in the amplified nucleolar chromatin of Physarum, Dictyostelium, and Tetrahymena which form linear strands with two rRNA genes at either end in a palindromic arrangement (Fig. 4 a; cf. Grainger and Ogle 1978; Grainger and Maizels 1980; Seebeck and Braun 1982; Vavra et al. 1982; Engberg 1985).

3. Transcribed nucleolar chromatin, as well as the intervening spacers are devoid of nucleosomes. The absence of nucleosomes is compatible with the full extension of the rDNA to the length of its B-form in Miller spreads. This has been shown by the congruence of the lengths of rDNA repeating units at the DNA and chromatin level (Trendelenburg et al. 1976; Scheer et al. 1977; Reeder et al. 1978) and by estimation of the DNA length contained in ribosomal transcription units by gel electrophoretic determinations of the molecular weight of the pre-rRNAs (e.g., Meyer and Hennig 1974; Scheer et al. 1977; Spring et al. 1976).

In Miller spreads the chromatin structure of active rDNA is readily distinguished from inactive chromatin. Providing that the transcripts are more distantly spaced, thus allowing visualization of the underlying chromatin axis, active rDNA has a thin, nonbeaded conformation (Fig. 3 b, c; see also Franke et al. 1976 b, 1978; Scheer 1978; Foe 1978; Busby and Bakken 1980; Labhart and Koller 1982; Scheer and Zentgraf 1982; Puvion-Dutilleul 1983). A similarly extended, nonnucleosomal organization has also been found for the nontranscribed spacer of several species (Fig. 3 a-c; Trendelenburg et al. 1976; Scheer et al. 1977; Scheer 1980; Scheer and Zentgraf 1982; Labhart and Koller 1982). That the nonnucleosomal conformation of nucleolar chromatin is maintained even when transcriptional activity is reduced suggests that the altered chromatin conformation is due to an intrinsic property of rDNA chromatin and not the transcription process per se (Fig. 3 c; Foe 1978; Scheer 1978). Only in stages of complete inactivation does rDNA-containing chromatin assume the characteristic nucleosomal conformation (see next section). The most compelling evidence for a stable extension of the DNA of both the gene and the spacer of transcribing nucleolar chromatin is found in studies of the circular rRNA genes of Dytiscus oocytes (Fig. 4 b; see also Trendelenburg et al. 1976). These circles contain one or more repeating units and, therefore, fall into discrete size classes. The rDNA can be isolated from the chromatin rings and surface spread by the cytochrome c-method (Fig. 4c). The identical contour lengths of both the chromatin rings and the corresponding rDNA circles indicate that the rDNA is fully extended in the chromatin (see also Trendelenburg et al. 1976; Scheer and Zentgraf 1978).

The central nontranscribed chromatin regions separating the palindromically arranged rRNA genes of Physarum, Dictyostelium, and Tetrahymena are exceptional in that they reveal a bead-like pattern, indicative of a nucleosomal organization (Fig. 4 a). In fact, the DNA of this intergene region is compacted by a factor of about 2 relative to the length of the corresponding DNA (Fig. 4 a; see also Grainger and Ogle 1978) and reveals the characteristic canonical nucleosome repeat after nuclease digestion (Borchsenius et al. 1981; Prior et al. 1983; Palen and Cech 1984). 


\section{1 rRNA Genes in Different States of Activity}

Ultrastructural studies of several biological systems have provided considerable insight into the regulation of rRNA synthesis. During insect embryogenesis and amphibian oogenesis, the rate of rRNA accumulation is extensively modulated (Foe 1978; McKnight and Miller 1976; Scheer et al. 1976 a). Using these systems, it is possible to examine rRNA genes by the Miller spreading technique in states of increasing and decreasing rRNA synthesis. Such studies have shown that rRNA synthesis is regulated at the level of transcription since reduced rRNA synthesis is correlated with a decreased number of transcripts per gene (Fig. 3 c) and/ or a decreased number of active genes. Furthermore, it has been demonstrated that rRNA gene activation proceeds via a two-step mechanism. First, there is a structural transition of rDNA chromatin from a beaded to a smooth form, which is then followed by transcription (Foe 1978; Scheer 1978). Each rRNA gene appears to be regulated individually since adjacent genes reveal variable degrees of transcript densities. The same pattern of chromatin reorganization is seen after inactivation of rRNA genes, both in natural stages of inactivation (e.g., Trendelenburg and McKinnell 1979) or after inhibition of transcription by drugs, such as actinomycin D (Scheer 1978; Franke et al. 1979). Long-term inactivated nucleolar chromatin is structurally indistinguishable from the bulk chromatin. Not only is it condensed into nucleosomes, but it is also organized into thick, i.e., higher order, fibrils (Scheer and Zentgraf 1978).

\section{Visualization of Transcriptionally Active Nonnucleolar Genes}

The electron microscopic chromatin spreading method has also provided new approaches to analyze the structural organization of transcriptionally active nonnucleolar genes and, in a few cases, to identify the transcription units of specific protein coding genes. The first nonnucleolar genes to be visualized in the electron microscope were the transcriptional units of the lateral loops of lampbrush chromosomes from amphibian oocytes (Miller and Beatty 1969d). Amphibian lampbrush chromosomes are especially well suited for such studies since their numerous lateral loops represent sites of intense transcriptional activities. As shown originally by Miller and co-workers and subsequently by other authors, loop transcription units are characterized by a high packing density of RNA polymerases (of type II, see Bona et al. 1981) and by nascent RNP transcripts reaching considerable lengths (Miller and Beatty 1969 d; Miller and Hamkalo 1972; Miller et al. 1972; Miller and Bakken 1972; Miller 1981; Angelier and Lacroix 1975; Franke et al. 1976 b; Scheer et al. 1976b, 1979 a; Hill 1979; Hill and McGregor 1980).

The light microscopic appearance of isolated lampbrush chromosomes from a salamander oocyte is presented in Fig. 5 a. Usually one loop represents a single transcription unit. Occasionally, however, a single loop contains more than one 


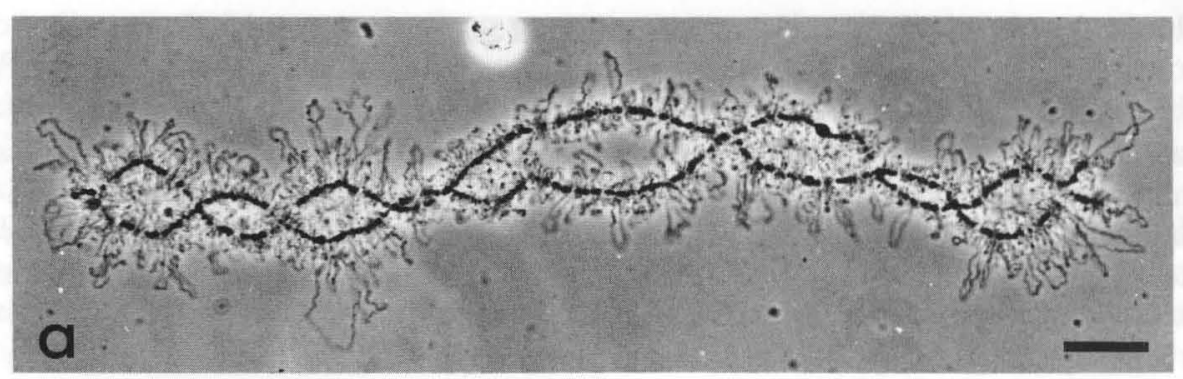

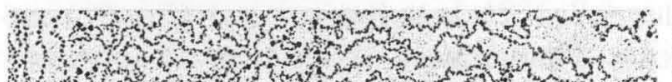

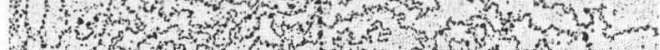

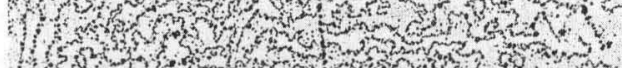

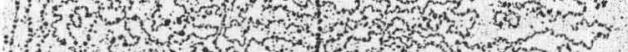

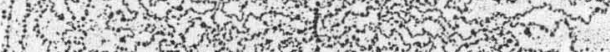

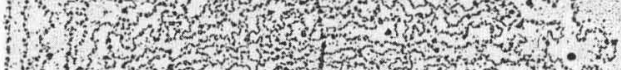

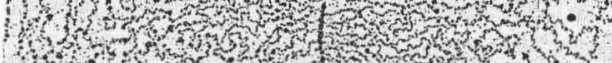

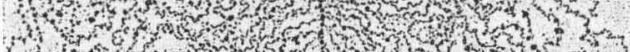

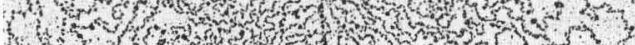

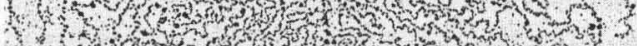

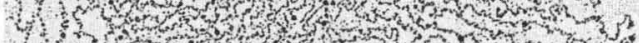

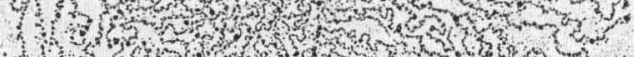

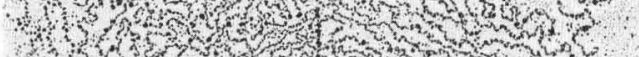

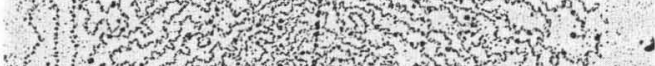

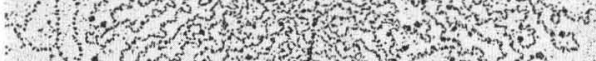
7 wh

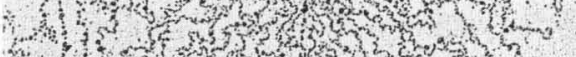
4. tor.
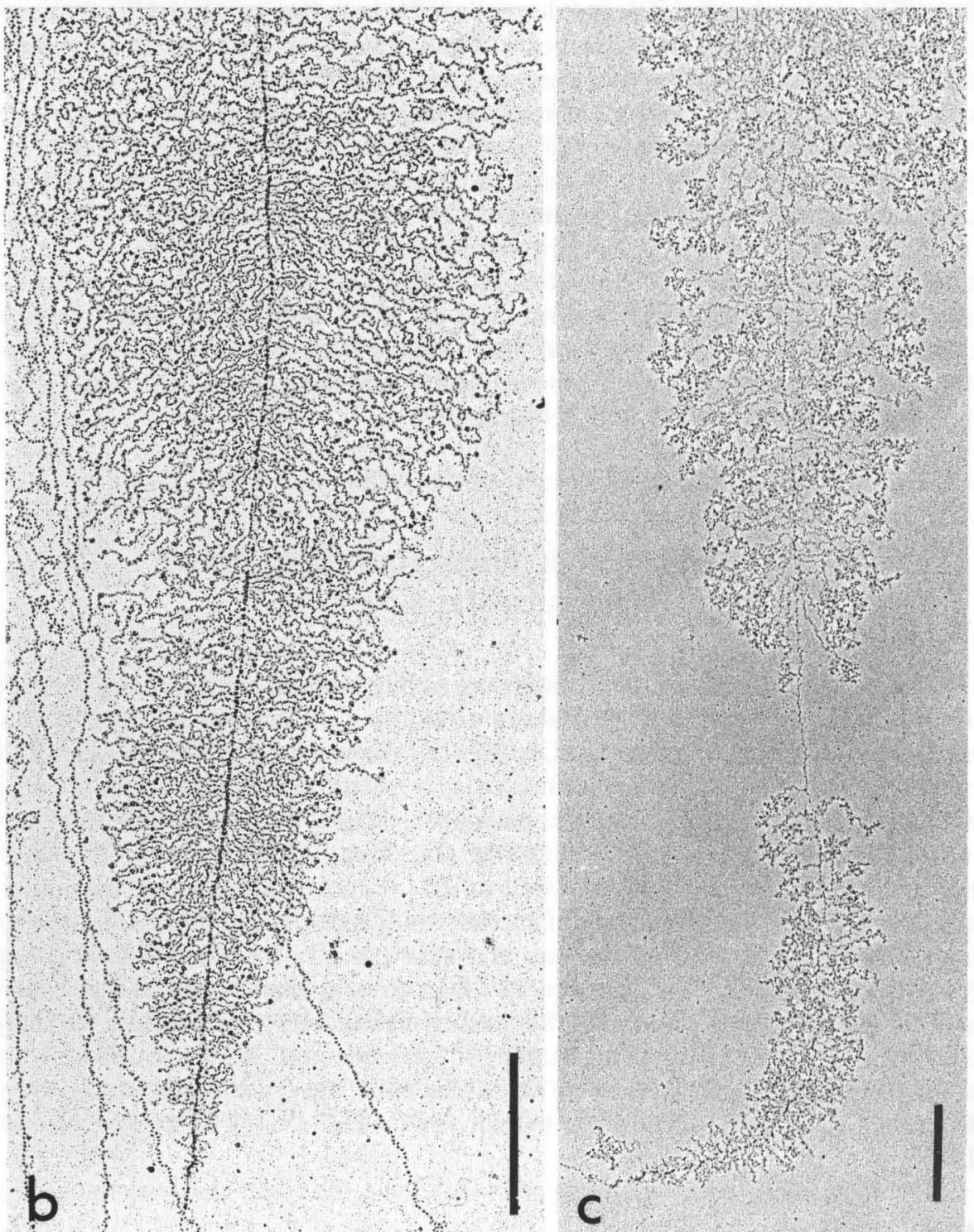

Fig. 5a-c 
transcription unit arranged with identical, opposite, or alternating polarities (Scheer et al. 1976b). Often the transcriptional polarity is recognized by the increase in thickness of the loop matrix between both ends of a loop (for a detailed account of lampbrush chromosome features see Callan 1982). In spread preparations transcriptional units of the lampbrush chromosomes (or fragments therefrom) are identified by their large size, the close spacing of transcripts, and the
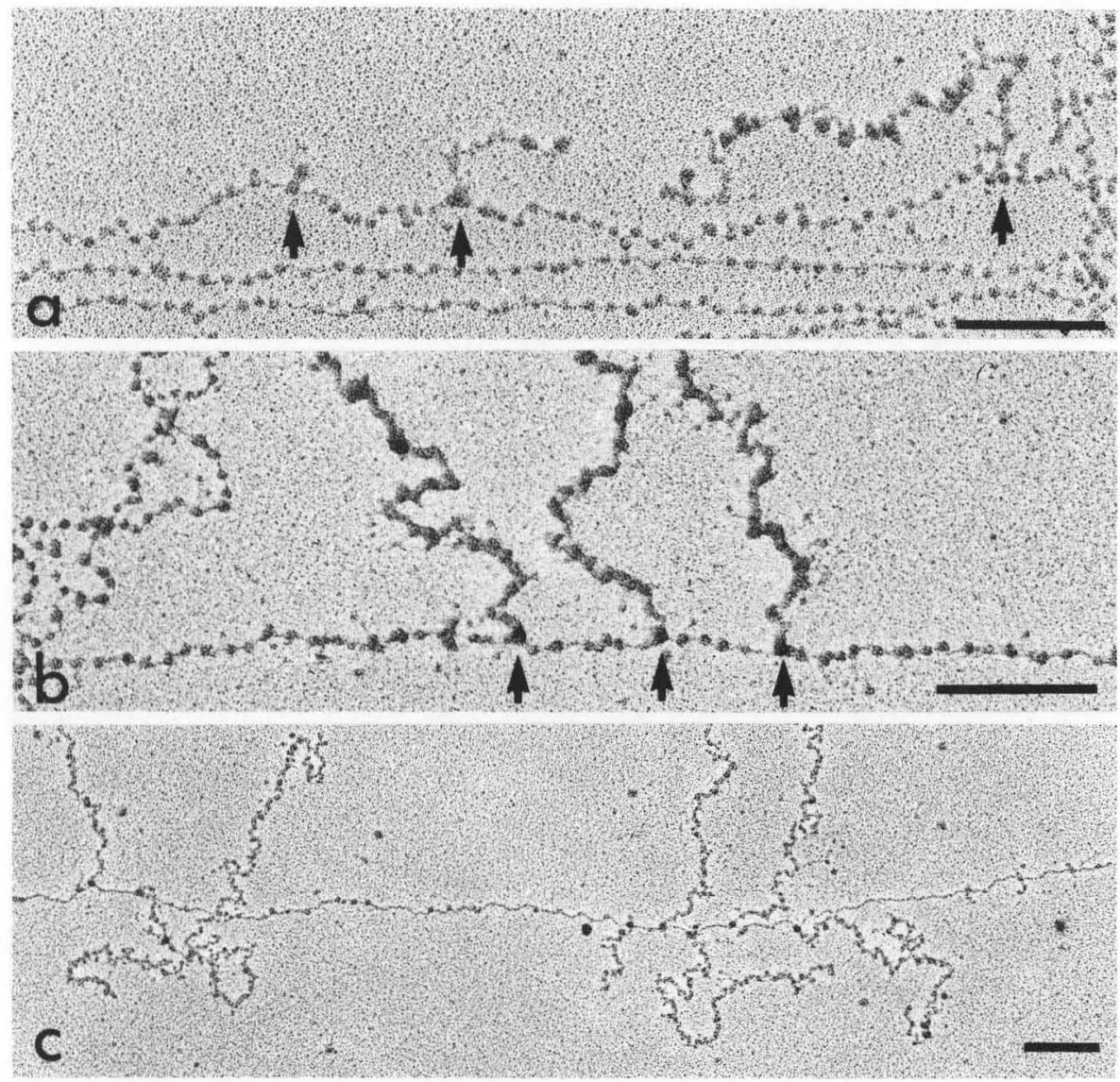

Fig.6a-c. Nucleosomal organization of moderately transcribed nonnucleolar chromatin from cultured Xenopus laevis kidney cells (a) and oocytes of Pleurodeles waltlii (b). The attachment sites of the transcripts to the chromatin axis are denoted by arrows. Inclusion of the anionic detergent Sarkosyl in the spreading medium releases the histones from the DNA and destroys the beaded organization $(\mathbf{c})$. The transcripts remain stably bound to the DNA under such conditions. a $\times 80000 ; \mathbf{b} \times 85000 ; \mathbf{c} \times 40000 ;$ bars $=0.2 \mu \mathrm{m}$

Fig. 5. a Light microscopic appearance of a lampbrush chromosome bivalent from a Pleurodeles waltlii oocyte. The lateral loops represent loci of intense transcriptional activity. b-c Miller spreads of lampbrush chromosomes from Pleurodeles walttii oocytes. Note the different morphological aspects of the nascent transcripts in $\mathbf{b}$ and $\mathbf{c} . \mathbf{a} \times 430 ; \mathbf{b} \times 20000 ; \mathbf{c} \times 12000 ;$ bars $=20 \mu \mathrm{m}$

(a) and $1 \mu \mathrm{m}(\mathbf{b}, \mathbf{c})$ 


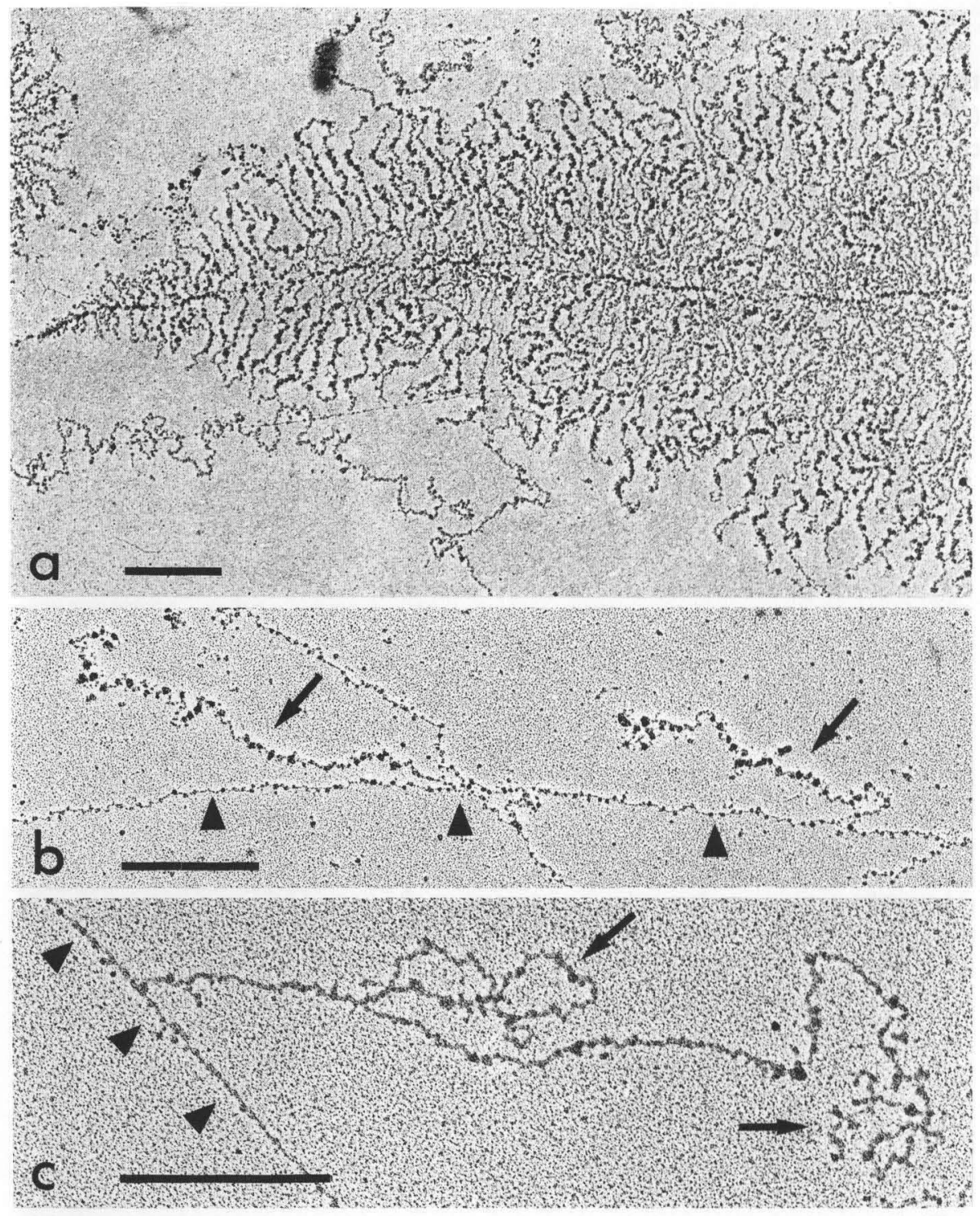

Fig. 7 a-c. Various aspects of transcript organization in Miller spreads of lampbrush chromosomes of Triturus cristatus (a) and cultured kidney cells of Xenopus laevis (b, c). Each transcript of the transcription unit shown in (a) reveals a subterminal thickening at corresponding positions. The two distantly spaced transcripts in b (arrows) are condensed into arrays of globular particles. Secondary structures characteristic of nonnucleolar transcripts (ring- and bushlike formations) are shown in (arrows). The chromatin axis is indicated by arrowheads in $\mathbf{b}$ and $\mathbf{c}$. a $\times 24000 ; \mathbf{b} \times 34000 ; \mathbf{c} 54000 ;$ bars $=0.5 \mu \mathrm{m}$

Fig. 8a, b. Part of a lampbrush loop transcription unit from a Triturus helveticus oocyte after spreading for electron microscopy according to the Miller procedure. Each lateral fibril carries a conspicuous "loop-stem" structure at corresponding positions (arrows in b). A transcript fibril from the terminal region of the same transcription unit is shown in (a). In addition to the loopstem structure indicated by the arrow a second fold-back structure of the nascent RNA is visible (arrowhead). Note that the double-stranded RNA "stem" structures are almost devoid of a protein coat. $\times 60000$; bars $=0.2 \mu \mathrm{m}$ 


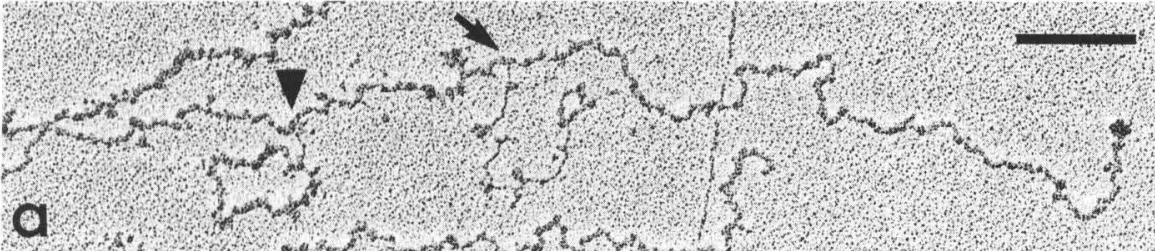

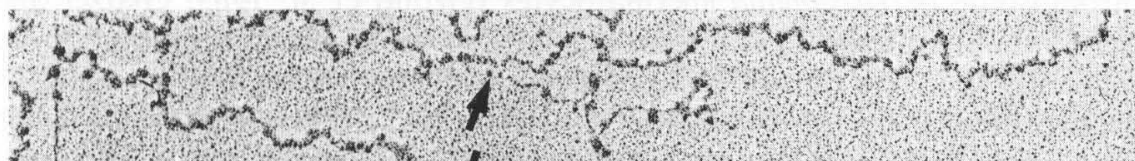

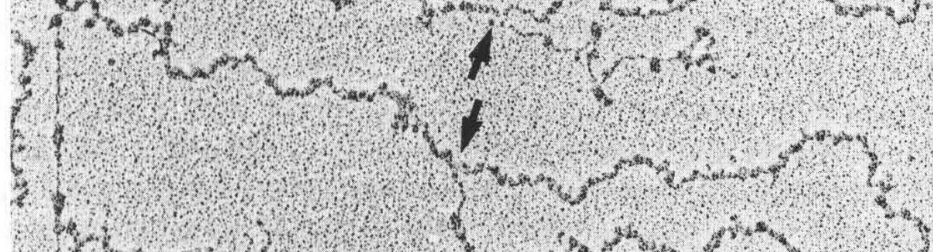

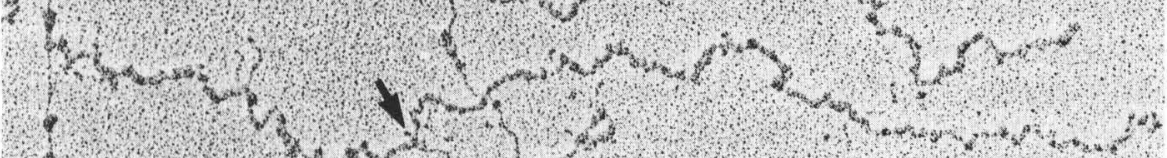

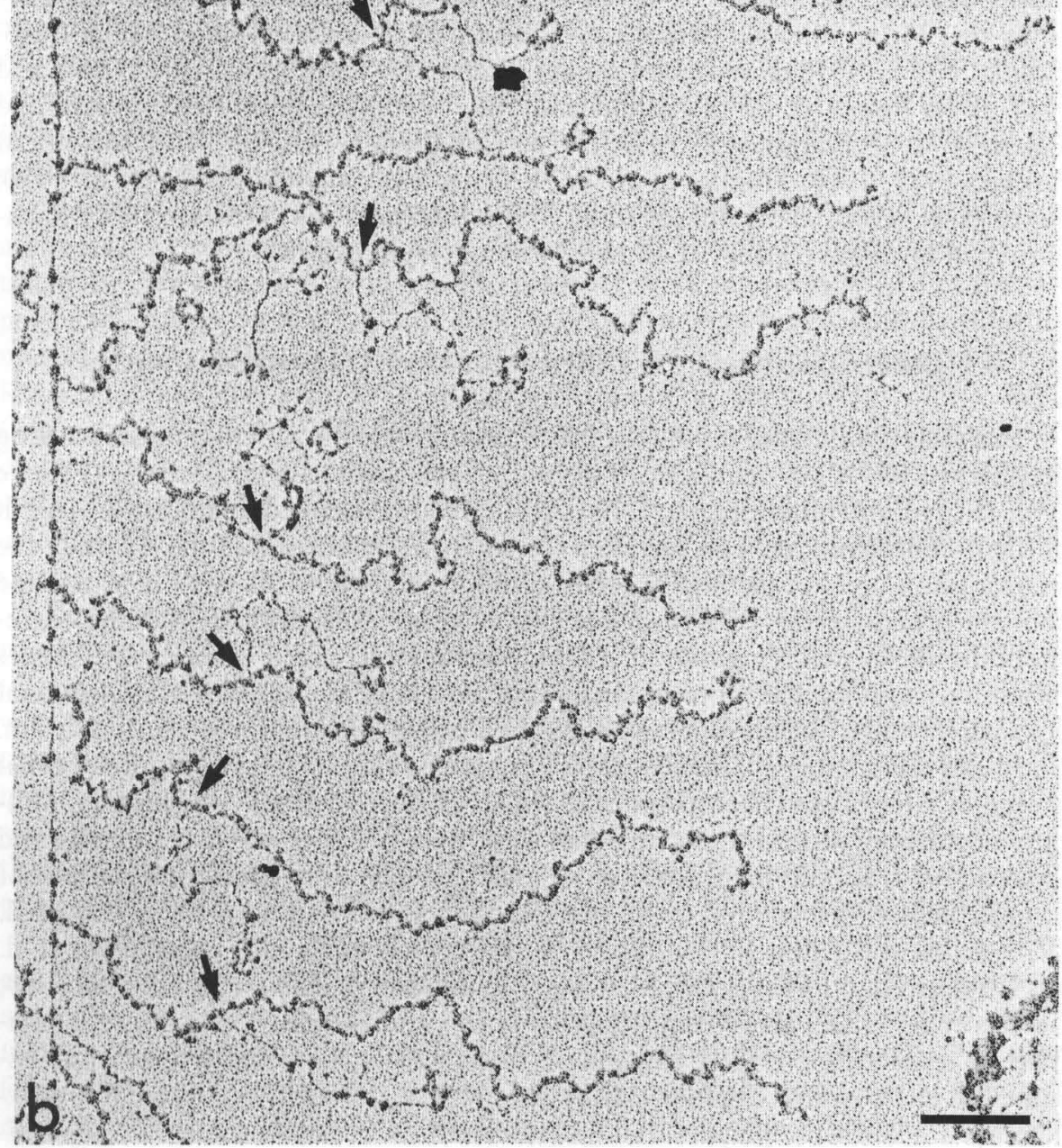

Fig. 8a, b 
extensive secondary structures of the transcript fibrils which often give rise to complex bush- and ring-like configurations (Figs. 5 b, c, 7 a, 8 a, b; for reviews see Scheer et al. 1979a; Sommerville 1981).

Similar high packing densities of nascent transcripts are also found in lampbrush chromosomes of the unicellular green algae, Acetabularia (Spring et al. 1975; Franke et al. 1976 b; Scheer et al. 1979 a), in certain lampbrush loops of the Y-chromosome of Drosophila spermatocytes (Grond et al. 1983; Glätzer and Meyer 1981), in autosomal chromosomes of Drosophila primary spermatocytes (Glätzer 1975), in silk fibroin genes of Bombyx mori (McKnight et al. 1976), in chorion protein genes of Drosophila (Osheim and Miller 1983; Osheim et al. 1985), and in Balbiani ring genes of polytene chromosomes from Chironomus tentans salivary glands (Lamb and Daneholt 1979; Widmer et al. 1984). Usually, however, nonnucleolar transcription units of a variety of cell types and species are characterized by relatively few transcript fibrils, with extended unoccupied chromatin regions, indicative of a low level of ongoing transcriptional activity (Figs. 6a, 7b, c; see also Miller and Bakken 1972; Hamkalo and Miller 1973; Hamkalo et al. 1973; Kierszenbaum and Tres 1975; Laird and Choii 1976; Laird et al. 1976; Foe et al. 1976; Amabis and Nair 1976; Oda et al. 1977; Villard and Fakan 1978; McKnight et al. 1979; Harper and Puvion-Dutilleul 1979; Busby and Bakken 1979, 1980; Hughes et al. 1979; Cotton et al. 1980; Petrov et al. 1980; Beyer et al. 1980, 1981; Scheer et al. 1981; Greimers and Deltour 1981; Bachvarova et al. 1982; Rattner et al. 1982; Puvion-Dutilleul 1983).

\subsection{Chromatin Structure in Different States of Transcriptional Activity}

Intensely transcribed nonnucleolar chromatin regions with maximum packing densities of RNA polymerases are devoid of nucleosome-sized particles (Franke et al. 1976 b). Furthermore, the DNA appears to be extended to almost the length of the B-conformation. This has been shown by a comparison of the length of the transcription units of the highly active silk fibroin genes of Bombyx mori and the chorion protein genes of Drosophila melanogaster follicle cells with the corresponding DNA (McKnight et al. 1976; Osheim et al. 1985). However, in stages of reduced activity and more distantly spaces transcripts, the chromatin axis not engaged in transcription generally assumes a beaded, nucleosomal configuration. The rapid reformation of nucleosomes after the passage of a transcriptional event is seen in lampbrush chromosomes in stages of experimentally induced or naturally occurring reduced transcriptional activity (Fig. 6 b, c; see also Angelier and Lacroix 1975; Scheer 1978; Bona et al. 1981), as well as in transcription units of somatic cells (Figs. 6a, 7b, c; see also Kierszenbaum and Tres 1975; Foe et al. 1976; Laird and Choii 1976; Laird et al. 1976; Oda et al. 1977; McKnight et al. 1979; Villard and Fakan 1978; Busby and Bakken 1979, 1980; Hughes et al. 1979; Cotton et al. 1980; Petrov et al. 1980; Greimers and Deltour 1981). Thus, in contrast to transcribing rDNA chromatin, nonnucleolar chromatin appears to assume the nucleosomal organization relatively fast, provided that the RNA polymerases are sufficiently apart to allow reformation of nucleosomes (for identification of nucleosomes in Miller spreads see below). 


\subsection{Ultrastructure of Nascent RNP Transcripts}

The specific low salt chromatin spreading conditions induce the nascent RNP fibrils to unravel from a condensed into a largely extended state. This is best illustrated by comparing the in situ conformation of nascent RNP transcripts of amphibian lampbrush chromosomes with their appearance in spread preparations. When lampbrush chromosomes are isolated in the presence of physiological salt concentrations followed by fixation and flat embedding for electron microscopy, ultrathin sections reveal that the majority of the transcripts are arranged in linear arrays consisting of 25 to $40 \mathrm{~nm}$ globular subunits (Mott and Callan 1975; Spring and Franke 1981; N'Da et al. 1986). In contrast, in Miller spreads much thinner fibrils of the transcripts predominate (Figs. $5 \mathrm{~b}, \mathrm{c}, 6 \mathrm{~b}, \mathrm{c}$ ) which apparently are derived by relaxation of the higher order globular packaging structures (see also Sommerville 1981; Scheer and Dabauvalle 1985). An ordered packaging of the basic $10 \mathrm{~nm}$ transcript fibril into a RNP particle of defined morphology and size has also been described for the transcripts of the Balbiani ring genes in Chironomus tentans (Skoglund et al. 1983). It should be noted that the extended transcripts as seen in Miller spreads are much thicker than naked RNA, indicating that the nascent RNA chains become coated with proteins immediately following their synthesis.

Not all RNP transcripts unravel into extended fibrils when spread for electron microscopy. Some retain extensive secondary structures and/or display a distinctly beaded morphology due to the presence of $20 \mathrm{~nm}$ particles. Examples are presented in Figs. 5c, 6a, $7 \mathrm{a}-\mathrm{c}$, and $8 \mathrm{a}, \mathrm{b}$, both from amphibian lampbrush chromosomes and cultured Xenopus laevis kidney cells (for further examples see, e.g., Kierszenbaum and Tres 1975; Hughes et al. 1979; Beyer et al. 1980, 1981; Greimers and Deltour 1981; Osheim et al. 1985). A remarkably high degree of secondary structure occurs along the transcripts of the $\mathrm{Y}$ chromosome in spermatocytes of Drosophila hydei. The transcripts possess a folding pattern that is characteristic for a specific transcription unit (Glätzer 1975; Glätzer and Meyer 1981; Grond et al. 1983; de Loos et al. 1984; Hennig 1985).

To what extent intramolecular base pairing of the nascent RNA chain or protein-protein interactions are involved in establishing the secondary structures of transcript fibrils seen in Miller spreads is not known (for discussion see Sommerville 1981). Several authors have analyzed the distribution of secondary structures, such as loop formations, bush-like ramifications, or RNP particles, in the multiple transcripts of a given transcription unit. The conclusion stemming from such studies is that secondary structures are not randomly distributed. Rather, they occur at specific sites indicating a relationship to specific RNA sequences (e.g., Glätzer 1980; Beyer et al. 1980; Hennig 1985; Osheim and Beyer 1985).

Two transcription units of Pleurodeles lampbrush chromosomes with different types of transcript organization are shown in Fig. 5 b and c. The transcripts are either fully extended (Fig. 5 b) or display, specifically at their termini, a particulate morphology and are folded up into complex bush-like structures (Fig. 5c). Another example is shown in Fig. 7 a where the subterminal region of each consecutive transcript carries an array of closely spaced particles at corresponding positions. 
A clear example that the RNA of nascent transcripts can form intramolecular duplex structures, probably by a fold-back mechanism and base pairing of inverted repeat sequences, is provided in Fig. 8. Two different loop-stem structures are recognized, a large loop with a short stem and a small loop with a long stem (Fig. 8 a). The loops presumably contain single-stranded RNA, whereas the stems are formed by duplex regions of the RNA (cf. Sommerville 1981). It is noteworthy that the loops display the same ultrastructural morphology as the principal RNP fibril. However, the stem connecting the loop to the transcript fibril is very thin and is apparently deficient of proteins. This finding is in agreement with biochemical studies showing that double-stranded RNA regions of hnRNA, in comparison with single-stranded regions, are relatively devoid of proteins in living cells (Calvet and Pederson 1979). The loop-stem structures form at corresponding positions of the multiple transcripts shown in Fig. 8 b. The micrograph depicts only a relatively small area close to the transcription initiation site where the second loop has not yet been formed. It is obvious that the distance between the hairpin structures and the anchoring sites of the fibrils into the chromatin axis increase as a function of the growth of the transcripts. A quantitative analysis of the total transcription unit with 48 traceable fibrils is presented in Fig. 9.

Whether the foldback structures of the type depicted in Fig. 8 have a function in the process of RNA sequence excision is presently not known. However, RNA particles frequently seen on transcripts of a given gene, at sequence-specific sites, might be functionally involved in splicing reactions by bringing together two splice junctions with the intron transcript looping out (Osheim et al. 1985; Osheim

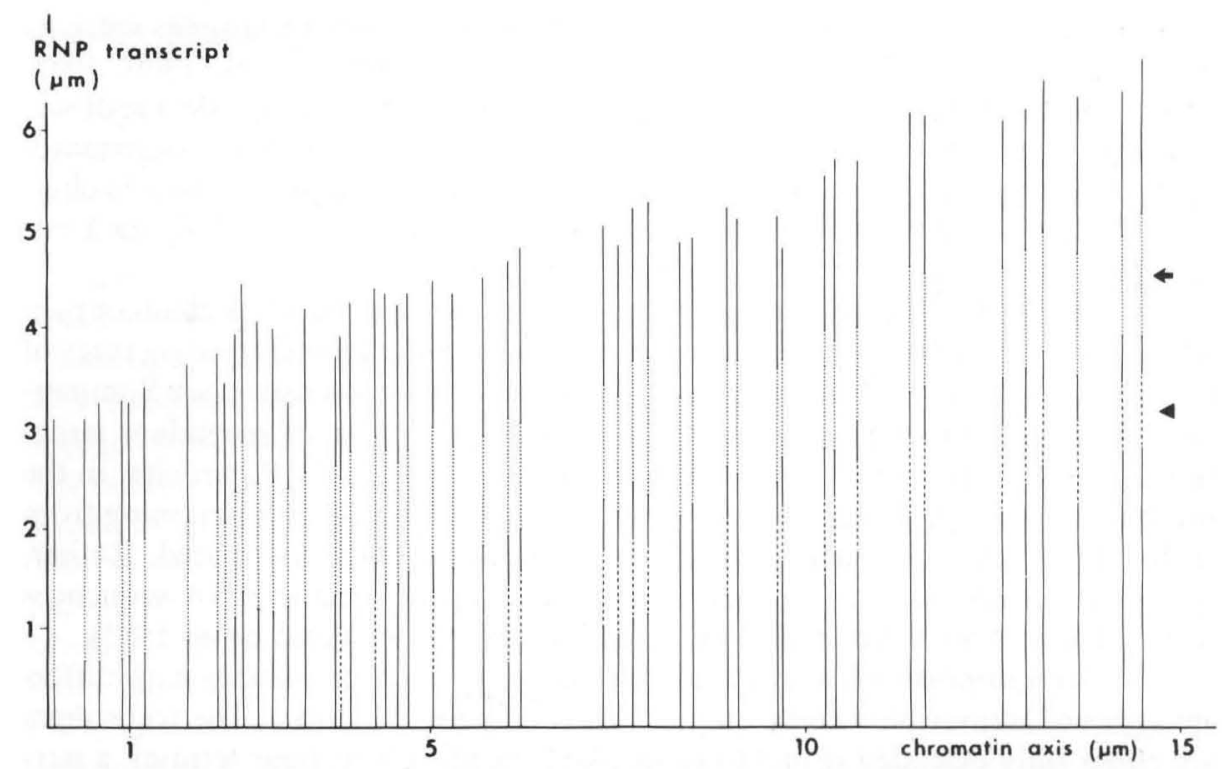

Fig.9. Quantitative evaluation of 48 traceable transcripts from the transcription unit shown in Fig. 8. Each transcript is represented in its linearized form, i.e., loop-stem structures are linearized and indicated as dotted lines (at the arrow and arrowhead; the corresponding structures are shown in Fig. 8 a). The graphic representation clearly demonstrates that the hairpin structures are related to specific sequences of the nascent RNA chains 
and Beyer 1985). Such splicing reactions might well occur during transcription. In fact, numerous nonnucleolar transcription units from a variety of species analyzed by the chromatin spreading method reveal interruptions in the RNP fibril length gradients. This indicates that cleavage of transcripts occurs during transcription (e.g., Laird and Choii 1976; Scheer et al. 1979 a; Beyer et al. 1981). In addition, a considerable proportion of the RNA contained in terminal transcript fibrils of amphibian lampbrush chromosomes apparently does not consist of contiguous chains, but of nicked molecules (Scheer and Sommerville 1982).

\section{Application of Localization Techniques to Miller Spreads}

An advantage of the chromatin spreading technique is that it is potentially capable of elucidating the ultrastructure and biochemical composition of transcription units of defined genes in various states of activity. So far only a few proteincoding genes have been identified in Miller spreads (silk fibroin genes of Bombyx mori: McKnight et al. 1976; Balbiani ring genes of salivary glands of Chironomus tentans: Lamb and Daneholt 1979; and chorion protein genes of Drosophila melanogaster follicle cells: Osheim and Miller 1983; Osheim et al. 1985). With the availability of specific nucleic acid probes it should be feasible, by using modified protocols for in situ hybridization, to correlate transcription units in Miller spreads with specific genes. In this way one may analyze the distribution of specific proteins within the transcription unit, in the flanking regions, and along the nascent RNP transcripts by immunochemical approaches.

\subsection{In Situ Hybridization of Nucleic Acids}

Transcription units with numerous attached lateral fibrils represent a favorable situation for in situ hybridization of DNA or RNA probes to the nascent RNA chains because of the multiplication of the DNA coding sequence at the RNA level. Hybridization of nucleic acid probes to nascent RNA has already been used, at the light microscopic level, to localize histone genes to specific loops of amphibian lampbrush chromosomes (Old et al. 1977; Callan 1982; Gall et al. 1981; Diaz et al. 1981; Diaz and Gall 1985).

Similar procedures may also be adapted to investigations at the electron microscopic level. Visualization of the hybridized DNA or RNA probe could be accomplished by autoradiographic or nonradioactive methods, such as biotinylation or chemical modification of the probe which are then detected by specific antibodies (e.g., Fostel et al. 1984; Landegent et al. 1985).

When recombinant plasmids containing rDNA sequences of Xenopus laevis are hybridized to Miller spreads of amphibian oocyte nuclei, the DNA probe binds selectively to the pre-rRNA of the lateral fibrils of the rRNA genes (for examples see Scheer and Zentgraf 1982). We are confident that further refinements of this approach will permit a better ultrastructural preservation of the transcrip- 
tion units and a higher hybridization efficiency so that protein coding genes can be identified as well.

An additional approach to identify transcribed genes in the electron microscope is based on restriction endonuclease cleavage prior to chromatin spreading in order to produce identifiable fragments of transcription units (e.g., Reeder et al. 1976; Pruitt and Reeder 1984).

\subsection{Biochemical and Immunological Techniques}

It is known that transcriptional complexes are extremely stable to high salt concentrations and ionic detergents, i.e., conditions which lead to the dissociation of the majority of chromatin proteins including histones (for details see Scheer 1978). This selective stability of transcriptional complexes has been exploited to demonstrate that the beaded morphology of a chromatin fiber is dependent on the presence of histones and does not reflect, e.g., arrays of template-bound RNA polymerases without nascent transcripts. When chromatin is spread in the presence of the anionic detergent Sarkosyl or the commercial dishware detergent "Joy" (originally introduced by Miller and Bakken 1972) at concentrations which release most chromatin proteins from the DNA, the beaded organization of chromatin is no longer visible (Scheer 1978). Figure $6 \mathrm{~b}$ and $\mathrm{c}$ illustrate the effect of Sarkosyl on the ultrastructure of lampbrush chromosome loops transcribed with moderate efficiency. Without detergent the chromatin axis displays a beaded morphology (Fig. 6b); addition of Sarkosyl results in the disappearance of the beads while the transcripts remain attached to the smoothly contoured chromatin fiber (Fig. 6c), indicating that the beads in fact represent nucleosomes.

A direct approach to localize specific proteins in Miller spreads is based on the use of immunolocalization techniques. As shown by several authors, antibodies to core histones react specifically with nucleosomal beads of inactive chromatin (e.g., Bustin et al. 1976; Ghose et al. 1983). Antibodies to the core histones $\mathrm{H} 2 \mathrm{~B}$ and $\mathrm{H} 3$ also bind to the axis of nonnucleolar genes which are sparsely covered with transcripts (McKnight et al. 1978). The identification of histones by this immuno-electron microscopic approach in conjunction with the beaded morphology of the chromatin regions between distantly spaced transcripts clearly indicates that a transient nucleosomal packaging of the chromatin template takes place between successive transcriptional events.

Whether histones remain associated also with intensely transcribed chromatin regions, such as the lampbrush chromosome loops or nucleolar chromatin, is as yet an open question (for discussion see Mathis et al. 1980; Karpov et al. 1984; Sargan and Butterworth 1985). Indirect evidence based on the effect of histone antibodies microinjected into nuclei of living amphibian oocytes suggests that some histones are present on the heavily transcribed lampbrush loops. However, these experiments did not allow quantitative estimates and also did not permit the precise localization of histones (Scheer et al. 1979 b; Scheer 1986).

Immuno-electron microscopy has also been used to study, at a very high level of resolution, the distribution of nonhistone proteins in chromatin. T-antigen has been mapped to a specific region of SV40 minichromosomes, the nucleosome- 
and histone-free gap containing the origin of replication and promotor elements (Harper et al. 1984; Weiss et al. 1985).

Do specific ribosomal proteins bind to nascent pre-rRNA of rRNA genes? This question has been studied by Choii and Leiby (1981) by combining Miller spreads with immunolocalization techniques. They used two different protocols for binding of the antibodies. Either the antibodies were added directly to the lysed Drosophila embryonic cells followed by centrifugation of the chromatin onto the electron microscopic grid or rRNA genes were first immobilized on the grid followed by incubation with the antibodies. Their results show that individual ribosomal proteins bind to specific sequences of the nascent pre-rRNA. In this connection it should be emphasized that not all ribosomal proteins are involved in the early steps of ribosomal assembly, but become integrated into preribosomal particles only at more advanced stages of maturation (Hügle et al. 1985).

Another approach to localize nucleolus-specific proteins in Miller spreads was taken by Angelier et al. (1982). These authors adapted the silver staining method to spread preparations of rRNA genes of amphibian oocytes. They showed that silver staining proteins were preferentially associated with the transcribed rDNA and/or with the basal portions of the nascent RNP transcripts.

In conclusion, the tools and the probes necessary for identification and analysis of transcription units at the molecular level are presently available. Their application, in conjunction with the Miller chromatin spreading technique, should lead to a more detailed understanding of the conformational and compositional differences between active and inactive chromatin and the complex processes involved in generation and maturation of RNP transcripts.

Acknowledgments. I thank Dr. Frank Longo and Dr. Werner W. Franke for critical reading and correcting the manuscript and Dr. Marie-Christine Dabauvalle for quantitative evaluation of some micrographs. The work presented here received financial support from the Deutsche Forschungsgemeinschaft.

\section{References}

Amabis JM, Nair KK (1976) Ultrastructure of gene transcription in spermatocytes of Trichosia pubescens Morgante, 1969 (diptera: sciaridae). Z Naturforsch 31c:186-189

Angelier N, Lacroix JC (1975) Complexes de transcription d'origines nucléolaire et chromosomique d'ovocytes de Pleurodeles waltlii et P.poireti (amphibiens, urodèles). Chromosoma $51: 323-335$

Angelier N, Hemon D, Bouteille M (1979) Mechanisms of transcription in nucleoli of amphibian oocytes as visualized by high-resolution autoradiography. J Cell Biol 80:277-290

Angelier N, Hernandez-Verdun D, Bouteille M (1982) Visualization of Ag-NOR proteins on nucleolar transcriptional units in molecular spreads. Chromosoma 86:661-672

Bachvarova R, Burns JP, Spiegelman I, Choy J, Chaganti RSK (1982) Morphology and transcriptional activity of mouse oocyte chromosomes. Chromosoma 86:181-196

Bakken A, Morgan G, Sollner-Webb B, Roan J, Busby S, Reeder RH (1982) Mapping of transcription initiation and termination signal on Xenopus laevis ribosomal DNA. Proc Natl Acad Sci USA 79:56-60

Beermann S (1984) Circular and linear structures in chromatin diminution of Cyclops. Chromosoma $89: 321-328$ 
Berger S, Schweiger H-G (1982) Characterization and species differences of rRNA in algae. In: Busch H, Rothblum L (eds) The cell nucleus, vol 10. Academic Press, New York, pp 31-65

Beyer AL, Miller OL, McKnight SL (1980) Ribonucleoprotein structure in nascent hnRNA is nonrandom and sequence-dependent. Cell 20:75-84

Beyer AL, Bouton AH, Miller OL (1981) Correlation of hnRNP structure and nascent transcript cleavage. Cell 26:155-165

Bona M, Scheer U, Bautz EKF (1981) Antibodies to RNA polymerase II (B) inhibit transcription in lampbrush chromosomes after microinjection into living amphibian oocytes. J Mol Biol 151:81-99

Borchsenius S, Bonven B, Leer JC, Westergaard O (1981) Nuclease-sensitive regions on the extrachromosomal r-chromatin from Tetrahymena pyriformis. Eur J Biochem 117:245-250

Busby S, Bakken A (1979) A quantitative electron microscopic analysis of transcription in sea urchin embryos. Chromosoma 71:249-262

Busby S, Bakken A (1980) Transcription in developing sea urchins: electron microscopic analysis of cleavage, gastrula and prism stages. Chromosoma 79:85-104

Bustin M, Goldblatt D, Sperling R (1976) Chromatin structure visualization by immunoelectron microscopy. Cell 7:297-304

Callan HG (1982) Lampbrush chromosomes. Proc R Soc Lond B 214:417-448

Calvet JP, Pederson T (1979) Heterogeneous nuclear RNA double-stranded regions probed in living $\mathrm{HeLa}$ cells by crosslinking with the psoralen derivative aminomethyltrioxsalen. Proc Natl Acad Sci USA 76:755-759

Choii WY (1976) RNA transcription and ribosomal protein assembly in Drosophila melanogaster. In: King RC (ed) Handbook of genetics, vol 5. Plenum, New York, pp 219-265

Chooi WY, Leiby KR (1981) An electron microscopic method for localization of ribosomal proteins during transcription of ribosomal DNA: a method for studying protein assembly. Proc Natl Acad Sci USA 78:4823-4827

Cotton RW, Manes C, Hamkalo BA (1980) Electron microscopic analysis of RNA transcription in preimplantation rabbit embryos. Chromosoma 79:169-178

de Loos F, Dijkhof R, Grond CJ, Hennig W (1984) Lampbrush chromosome loop-specificity of transcript morphology in spermatocyte nuclei of Drosophila hydei. EMBO J 3:28452849

Diaz MO, Gall JG (1985) Giant readthrough transcription units at the histone loci on lampbrush chromosomes of the newt Notophthalmus. Chromosoma 92:243-253

Diaz MO, Barsacchi-Pilone G, Mahon KA, Gall JG (1981) Transcripts from both strands of a satellite DNA occur on lampbrush chromosome loops of the newt Notophthalmus. Cell 24:649-659

DuPraw EJ (1970) DNA and chromosomes. Holt, Rinehart and Winston, New York

Engberg J (1985) The ribosomal RNA genes of Tetrahymena: structure and function. Eur J Cell Biol 36:133-151

Foe VE (1978) Modulation of ribosomal RNA synthesis in Oncopeltus fasciatus: an electron microscopic study of the relationship between changes in chromatin structure and transcriptional activity. Cold Spring Harbor Symp Quant Biol 42:723-740

Foe VE, Wilkinson LE, Laird CD (1976) Comparative organization of active transcription units in Oncopeltus fasciatus. Cell 9:131-146

Fostel J, Narayanswami S, Hamkalo B, Clarkson SG, Pardue ML (1984) Chromosomal location of a major tRNA gene cluster of Xenopus laevis. Chromosoma 90:254-260

Franke WW, Scheer U (1978) Morphology of transcriptional units at different states of activity. Philos Trans R Soc Lond B 283:333-342

Franke WW, Scheer U, Spring H, Trendelenburg MF, Krohne G (1976a) Morphology of transcriptional units of rDNA. Exp Cell Res 100:233-244

Franke WW, Scheer U, Trendelenburg MF, Spring H, Zentgraf H (1976b) Absence of nucleosomes in transcriptionally active chromatin. Cytobiologie 13:401-434

Franke WW, Scheer U, Trendelenburg MF, Zentgraf H, Spring H (1978) Morphology of transcriptionally active chromatin. Cold Spring Harbor Symp Quant Biol 42:755-772

Franke WW, Scheer U, Spring H, Trendelenburg MF, Zentgraf H (1979) Organization of nucleolar chromatin. In: Busch H (ed) The cell nucleus, vol 7. Academic Press, New York, pp 49-95 
Gall JG (1963) Chromosome fibers from an interphase nucleus. Science 139:120-121

Gall JG (1966) Chromosome fibers studied by a spreading technique. Chromosoma 20:221233

Gall JG, Stephenson EC, Erba HP, Diaz MO, Barsacchi-Pilone G (1981) Histone genes are located at the sphere loci of newt lampbrush chromosomes. Chromosoma 84:159-171

Ghose D, Weiss E, Homo JC, Van Regenmortel MHV, Oudet P (1983) Visualization of antihistone antibodies on SV40 minichromosomes by scanning transmission electron microscopy (STEM). Exp Cell Res 147:135-142

Glätzer KH (1975) Visualization of gene transcription in spermatocytes of Drosophila hydei. Chromosoma 53:371-379

Glätzer KH (1980) Regular substructures within homologous transcripts of spread Drosophila germ cells. Exp Cell Res 125:519-523

Glätzer KH, Meyer GF (1981) Morphological aspects of the genetic activity in primary spermatocyte nuclei of Drosophila hydei. Biol Cell 41:165-172

Grainger RM, Maizels N (1980) Dictyostelium ribosomal RNA is processed during transcription. Cell 20:619-623

Grainger RM, Ogle RC (1978) Chromatin structure of the ribosomal RNA genes in Physarum polycephalum. Chromosoma 65:115-126

Greimers R, Deltour R (1981) Organization of transcribed and nontranscribed chromatin in isolated nuclei of Zea mays root cells. Eur J Cell Biol 23:303-311

Grond CJ, Siegmund I, Hennig W (1983) Visualization of a lampbrush loop-forming fertility gene in Drosophila hydei. Chromosoma 88:50-56

Hamkalo BA, Miller OL (1973) Electronmicroscopy of genetic activity. Annu Rev Biochem 42:379-396

Hamkalo BA, Miller OL, Bakken AH (1973) Ultrastructure of active eukaryotic genomes. Cold Spring Harbor Symp Quant Biol 38:915-919

Hamkalo BA, Goldsmith MR, Rattner JB (1981) Higher order structure in chromosomes. In: Schweiger HG (ed) International cell biology 1980-1981. Springer, Berlin Heidelberg New York, pp 152-161

Harper F, Puvion-Dutilleul F (1979) Non-nucleolar transcription complexes of rat liver as revealed by spreading isolated nuclei. J Cell Sci 40:181-192

Harper F, Florentin Y, Puvion E (1984) Localization of T-antigen on simian virus 40 minichromosomes by immunoelectron microscopy. EMBO J 3:1235-1241

Hennig W (1985) Y chromosome function and spermatogenesis in Drosophila hydei. Adv Genet 23:179-234

Herzog M, Soyer M-O (1981) Distinctive features of dinoflagellate chromatin. Absence of nucleosomes in a primitive species Prorocentrum micans E. Eur J Cell Biol 23:295-302

Hill RS (1979) A quantitative electron-microscope analysis of chromatin from Xenopus laevis lampbrush chromosomes. J Cell Sci 40:145-169

Hill RS, MacGregor HC (1980) The development of lampbrush chromosome-type transcription in the early diplotene oocytes of Xenopus laevis: an electron-microscope analysis. J Cell Sci 44:87-101

Howze GB, Hsie AW, Olins AL (1976) v-bodies in mitotic chromatin. Exp Cell Res 100:424 428

Hozier JC (1979) Nucleosomes and higher levels of chromosomal organization. In: Taylor JH (ed) Molecular genetics, part 3. Academic Press, New York, pp 315-385

Hügle B, Hazan R, Scheer U, Franke WW (1985) Localization of ribosomal protein S1 in the granular component of the interphase nucleolus and its distribution during mitosis. J Cell Biol 100:873-886

Hughes ME, Bürki K, Fakan S (1979) Visualization of transcription in early mouse embryos. Chromosoma 73:179-190

Igo-Kemenes T, Hörz W, Zachau HG (1982) Chromatin. Annu Rev Biochem 51:89-121

Karpov VL, Preobrazhenskaya OV, Mirzabekov AD (1984) Chromatin structure of hsp 70 genes, activated by heat shock: selective removal of histones from the coding region and their absence from the $5^{\prime}$ region. Cell 36:423-431

Kierszenbaum AL, Tres LL (1975) Structural and transcriptional features of the mouse spermatid genome. J Cell Biol 65:258-270 
Kornberg RD (1977) Structure of chromatin. Annu Rev Biochem 46:931-954

Labhart P, Koller T (1982) Structure of the active nucleolar chromatin of Xenopus laevis oocytes. Cell 28:279-292

Labhart P, Koller T, Wunderli H (1982) Involvement of higher order chromatin structures in metaphase chromosome organization. Cell 30:115-121

Laird CD, Chooi WY (1976) Morphology of transcription units in Drosophila melanogaster. Chromosoma 58:193-218

Laird CD, Wilkinson LE, Foe VE, Chooi WY (1976) Analysis of chromatin-associated fiber arrays. Chromosoma 58:169-192

Lamb MM, Daneholt B (1979) Characterization of active transcription units in Balbiani rings of Chironomus tentans. Cell 17:835-848

Landegent JE, Jansen in de Wal N, van Ommen GJB, Baas F, de Vijlder JJM, van Duijn P, van der Ploeg M (1985) Chromosomal localization of a unique gene by non-autoradiographic in situ hybridization. Nature 317:175-177

Lutz C, Nagl W (1980) A reliable method for preparation and electron microscopic visualization of nucleosomes in higher plant. Planta 149:408-410

Mathis D, Oudet P, Chambon P (1980) Structure of transcribing chromatin. Prog Nucleic Acid Res Mol Biol 24:1-55

McGhee JD, Felsenfeld G (1980) Nucleosome structure. Annu Rev Biochem 49:1115-1156

McKnight SL, Miller OL (1976) Ultrastructural patterns of RNA synthesis during early embryogenesis of Drosophila melanogaster. Cell 8:305-319

McKnight SL, Sullivan NL, Miller OL (1976) Visualization of the silk fibroin transcription unit and nascent silk fibroin molecules on polyribosomes of Bombyx mori. Prog Nucleic Acid Res Mol Biol 19:313-318

McKnight SL, Bustin M, Miller OL (1978) Electron microscopic analysis of chromosome metabolism in the Drosophila melanogaster embryo. Cold Spring Harbor Symp Quant Biol 42:741754

McKnight SL, Martin KA, Beyer AL, Miller OL (1979) Visualization of functionally active chromatin. In: Busch H (ed) The cell nucleus, vol 7. Academic Press, New York, pp 97122

Meyer GF, Hennig W (1974) The nucleolus in primary spermatocytes of Drosophila hydei. Chromosoma 46:121-144

Miller OL (1981) The nucleolus, chromosomes, and visualization of genetic activity. J Cell Biol $91: 15 \mathrm{~s}-27 \mathrm{~s}$

Miller OL (1984) Some ultrastructural aspects of genetic activity in eukaryotes. J Cell Sci Suppl $1: 81-93$

Miller OL, Bakken AH (1972) Morphological studies of transcription. Acta Endocrinol Suppl 168:155-177

Miller OL, Beatty BR (1969a) Visualization of nucleolar genes. Science 164:955-957

Miller OL, Beatty BR (1969 b) Extrachromosomal nucleolar genes in amphibian oocytes. Genetics Suppl 61:133-143

Miller OL, Beatty BR (1969 c) Nucleolar structure and function. In: Lima-de-Faria A (ed) Handbook of molecular cytology. North-Holland, Amsterdam, pp 605-619

Miller OL, Beatty BR (1969d) Portrait of a gene. J Cell Physiol 74: Suppl 1:225-232

Miller OL, Hamkalo BA (1972) Visualization of RNA synthesis on chromosomes. Int Rev Cytol 33:1-25

Miller OL, Beatty BR, Hamkalo BA (1972) Nuclear structure and function during amphibian oogenesis. In: Biggers JD, Schuetz AW (eds) Oogenesis. Univ Park Press, Baltimore; Butterworths, London, pp 119-129

Morgan GT, Reeder RH, Bakken AH (1983) Transcription in cloned spacers of Xenopus laevis ribosomal DNA. Proc Natl Acad Sci USA 80:6490-6494

Mott MR, Callan HG (1975) An electron-microscope study of the lampbrush chromosomes of the newt Triturus cristatus. J Cell Sci 17:241-261

N'Da E, Bonnanfant-Jais ML, Penrad-Mobayed M, Angelier N (1986) Size uniformity of ribonucleoprotein matrix particles in loops of Pleurodeles waltlii lampbrush chromosomes visualized by electron microscopy. J Cell Sci 81:17-27 
Oda T, Nakamura T, Watanabe S (1977) Transcription complexes of chromatin showing a beads-like structure of heterogeneous ribonucleoprotein chains. J Electron Microsc 26:203207

Old RW, Callan HG, Gross KW (1977) Localization of histone gene transcripts in newt lampbrush chromosomes by in situ hybridization. J Cell Sci 27:57-79

Olins AL, Olins DE (1973) Spheroid chromatin units (v bodies). J Cell Biol 59:252a

Olins AL, Olins DE (1974) Spheroid chromatin units (v bodies). Science 183:330-332

Olins AL, Carlson RD, Olins DE (1975) Visualization of chromatin substructure: v bodies. J Cell Biol 64:528-537

Osheim YN, Beyer AL (1985) Nascent ribonucleoprotein structure of polymerase I, II, and III gene transcripts. In: Smuckler EA, Clawson GA (eds) Nuclear envelope structure and RNA maturation. Liss, New York, pp 277-295

Osheim YN, Miller OL (1983) Novel amplification and transcriptional activity of chorion genes in Drosophila melanogaster follicle cells. Cell 33:543-553

Osheim YN, Miller OL, Beyer AL (1985) RNP particles at splice junction sequences on Drosophila chorion transcripts. Cell 43:143-151

Oudet P, Gross-Bellard M, Chambon P (1975) Electron microscopic and biochemical evidence that chromatin structure is a repeating unit. Cell 4:281-300

Palen TE, Cech TR (1984) Chromatin structure at the replication origins and transcription-initiation regions of the ribosomal RNA genes of Tetrahymena. Cell 36:933-942

Petrov P, Raitcheva E, Tsanev R (1980) Nucleosomes and nonribosomal RNA transcription in early mouse embryo. An electron microscopic study. Eur J Cell Biol 22:708-713

Prior CP, Cantor CR, Johnson EM, Littau VC, Allfrey VG (1983) Reversible changes in nucleosome structure and histone $\mathrm{H} 3$ accessibility in transcriptionally active and inactive states of rDNA chromatin. Cell 34:1033-1042

Pruitt SC, Reeder RH (1984) Effect of topological constraint on transcription of ribosomal DNA in Xenopus oocytes. J Mol Biol 174:121-139

Puvion-Dutilleul F (1983) Morphology of transcription at cellular and molecular levels. Int Rev Cytol 84:57-101

Puvion-Dutilleul F, Bernadac A, Puvion E, Bernhard W (1977) Visualization of two different types of nuclear transcriptional complexes in rat liver cells. J Ultrastruct Res 58:108-117

Rattner JB, Sauners C, Davie JR, Hamkalo BA (1982) Ultrastructural organization of yeast chromatin. J Cell Biol 92:217-222

Reeder RH, Higashinakagawa T, Miller OL (1976) The 5'-3' polarity of the Xenopus ribosomal RNA precursor molecule. Cell 8:449-454

Reeder RH, McKnight SL, Miller OL (1978) Contraction ratio of the nontranscribed spacer of Xenopus rDNA chromatin. Cold Spring Harbor Symp Quant Biol 42:1174-1177

Ris H (1969) The molecular organization of chromosomes. In: Lima-de-Faria A (ed) Handbook of molecular cytology. North-Holland, Amsterdam, pp 221-250

Ris H, Korenberg J (1979) Chromosome structure and levels of chromosome organization. In: Prescott DM, Goldstein L (eds) Cell biology, vol 2. Academic Press, New York, pp 267361

Sargan DR, Butterworth PHW (1985) Eukaryotic ternary transcription complexes: transcription complexes of RNA polymerase II are associated with histone-containing, nucleosome-like particles in vivo. Nucl Acids Res 13:3805-3822

Scheer U (1978) Changes of nucleosome frequency in nucleolar and non-nucleolar chromatin as a function of transcription: an electron microscopic study. Cell 13:535-549

Scheer U (1980) Structural organization of spacer chromatin between transcribed ribosomal RNA genes in amphibian oocytes. Eur J Cell Biol 23:189-196

Scheer U (1986) Injection of antibodies into the nucleus of amphibian oocytes: an experimental means of interfering with gene expression in the living cell. J Embryol Exp Morph 97 Suppl:223-242

Scheer U, Dabauvalle M-C (1985) Functional organization of the amphibian oocyte nucleus. In: Browder LW (ed) Developmental biology, vol 1. Plenum, New York, pp 385-430

Scheer U, Sommerville J (1982) Sizes of chromosome loops and hnRNA molecules in oocytes of amphibia of different genome sizes. Exp Cell Res 139:410-416 
Scheer U, Zentgraf H (1978) Nucleosomal and supranucleosomal organization of transcriptionally inactive rDNA circles in Dytiscus oocytes. Chromosoma 69:243-254

Scheer U, Zentgraf H (1982) Morphology of nucleolar chromatin in electron microscopic spread preparations. In: Busch H, Rothblum L (eds) The cell nucleus, vol 11. Academic Press, New York, pp 143-176

Scheer U, Trendelenburg MF, Franke WW (1976a) Regulation of transcription of genes of ribosomal RNA during amphibian oogenesis. A biochemical and morphological study. J Cell Biol 69:465-489

Scheer U, Franke WW, Trendelenburg MF, Spring H (1976b) Classification of loops of lampbrush chromosomes according to the arrangement of transcriptional complexes. J Cell Sci 22:503-519

Scheer U, Trendelenburg MF, Krohne G, Franke WW (1977) Lengths and patterns of transcriptional units in the amplified nucleoli of oocytes of Xenopus laevis. Chromosoma 60:147167

Scheer U, Spring H, Trendelenburg MF (1979a) Organization of transcriptionally active chromatin in lampbrush chromosome loops. In: Busch H (ed) The cell nucleus, vol 7. Academic Press, New York, pp 3-47

Scheer U, Sommerville J, Bustin M (1979 b) Injected histone antibodies interfere with transcription of lampbrush chromosome loops in oocytes of Pleurodeles. J Cell Sci 40:1-20

Scheer U, Zentgraf H, Sauer H (1981) Different chromatin structures in Physarum polycephalum. Chromosoma 84:279-290

Seebeck T, Braun R (1982) Organization of rDNA in chromatin: Physarum. In: Busch H, Rothblum L (eds) The cell nucleus, vol 11. Academic Press, New York, pp 177-191

Skoglund U, Andersson K, Björkroth B, Lamb MM, Daneholt B (1983) Visualization of the formation and transport of a specific hnRNP particle. Cell 34:847-855

Solari AJ (1974) The molecular organization of the chromatin fiber. In: Busch H (ed) The cell nucleus, vol 1. Academic Press, New York, pp 493-535

Sollner-Webb B, Wilkinson JK, Miller KG (1982) Transcription of Xenopus ribosomal RNA genes. In: Busch H, Rothblum L (eds) The cell nucleus, vol 12. Academic Press, New York, pp 31-67

Sommerville J (1981) Immunolocalization and structural organization of nascent RNP. In: Busch H (ed) The cell nucleus, vol 8. Academic Press, New York, pp 1-57

Spring H, Franke WW (1981) Transcriptionally active chromatin in loops of lampbrush chromosomes at physiological salt concentration as revealed by electron microscopy sections. Eur J Cell Biol 24:298-308

Spring H, Scheer U, Franke WW, Trendelenburg MF (1975) Lampbrush-type chromosomes in the primary nucleus of the green alga Acetabularia mediterranea. Chromosoma 50:25-43

Spring H, Krohne G, Franke WW, Scheer U, Trendelenburg MF (1976) Homogeneity and heterogeneity of sizes of transcriptional units and spacer regions in nucleolar genes of Acetabularia. Biol Cell 25:107-116

Trendelenburg MF (1981) Initiations of transcription at distinct promoter sites in spacer regions between pre-rRNA genes in oocytes of Xenopus laevis: an electron microscopic analysis. Biol Cell 42:1-12

Trendelenburg MF (1983) Progress in visualization of eukaryotic gene transcription. Hum Genet 63:197-215

Trendelenburg MF, McKinnell RG (1979) Transcriptionally active and inactive regions of nucleolar chromatin in amplified nucleoli of fully grown oocytes of hibernating frogs, Rana pipiens (amphibia, anura). Differentiation 15:73-95

Trendelenburg MF, Scheer U, Zentgraf H, Franke WW (1976) Heterogeneity of spacer lengths in circles of amplified ribosomal DNA of two insect species, Dytiscus marginalis and Acheta domesticus. J Mol Biol 108:453-470

Vavra KJ, Colavito-Shepanski M, Gorovsky MA (1982) Organization of rDNA in chromatin: Tetrahymena. In: Busch H, Rothblum L (eds) The cell nucleus, vol 11. Academic Press, New York, pp 193-223

Villard D, Fakan S (1978) Visualisation des complexes de transcription dans la chromatine étalée de mammifères: étude en autoradiographie à haute résolution. C R Acad Sci Paris 286D:777-780 
Weiss E, Ghose D, Schultz P, Oudet P (1985) T-antigen is the only detectable protein on the nucleosome-free origin region of isolated simian virus 40 minichromosomes. Chromosoma 92:391-400

Widmer RM, Lucchini R, Lezzi M, Meyer B, Sogo JM, Edström J-E, Koller T (1984) Chromatin structure of a hyperactive secretory protein gene (in Balbiani ring 2) of Chironomus. EMBO J 3:1635-1641

Woodcock CLF (1973) Ultrastructure of inactive chromatin. J Cell Biol 59:368a

Woodcock CLF, Safer JP, Stanchfield JE (1976) Structural repeating units in chromatin. Exp Cell Res 97:101-110

Zentgraf H, Müller U, Franke WW (1980a) Reversible in vitro packing of nucleosomal filaments into globular supranucleosomal units in chromatin of whole chick erythrocyte nuclei. Eur J Cell Biol 23:171-188

Zentgraf H, Müller U, Franke WW (1980 b) Supranucleosomal organization of sea urchin sperm chromatin in regularly arranged 40 to $50 \mathrm{~nm}$ large granular subunits. Eur J Cell Biol 20:254 264

Zentgraf H, Müller U, Scheer U, Franke WW (1981) Evidence for the existence of globular units in the supranucleosomal organization of chromatin. In: Schweiger HG (ed) International cell biology 1980-1981. Springer, Berlin Heidelberg New York, pp 139-151 